\title{
Penilaian Kinerja Guru Produktif Dalam Melaksanakan Standar Kompetensi Guru
}

\author{
Dedi Setiawan $^{1 *}$, Hendra Dani Saputra ${ }^{1}$, Muslim $^{1}$, R Chandra $^{1}$ \\ ${ }^{1}$ Jurusan Teknik Otomotif, Fakultas Teknik, Universitas Negeri Padang \\ *Corresponding author, e-mail: dedimpdt@ft.unp.ac.id
}

\begin{abstract}
Abstrak - Penelitian ini bertujuan untuk menilai kinerja guru produktif dalam melaksanakan standar kompetensi guru. Jenis penelitian ini adalah penelitian kombinasi (kuantitatif dan kualitatif). Subjek penelitian sebanyak 55 orang. Data penelitian diperoleh melalui kuesioner, teman sejawat, observasi, wawancara dan data hasilnya di analisis menggunakan rumus persentase. Hasil penelitian ditemukan bahwa kompetensi pedagogik: (1) Untuk kuesioner skor total rata-ratanya 4,2. (2) Untuk penilaian teman sejawat skor total rata-ratanya 4,0, dengan tingkat pencapaian responden $80 \%$ berada dalam kategori "baik", (3) Untuk observasi skor total rata-ratanya 4,0, dengan tingkat pencapaian responden $80 \%$ berada dalam kategori "baik", dan (4) Untuk hasil wawancara yang diajukan kepada kepala sekolah, waka kurikulum dan 7 ketua jurusan produktif, dengan kesimpulan kategori "baik". Sementara untuk kompetensi kepribadian diperoleh penilaian (1) Untuk kuesioner skor total rataratanya 4,3. (2) Untuk penilaian teman sejawat skor total rata-ratanya 4,2, dengan tingkat pencapaian responden $84 \%$ berada dalam kategori "baik", (3) Untuk observasi skor total rata-ratanya 4,1, dengan tingkat pencapaian responden $82 \%$ berada dalam kategori "baik", dan (4) Untuk hasil wawancara yang diajukan kepada kepala sekolah, waka kurikulum dan 7 ketua jurusan produktif yaitu dengan kesimpulan kategori "baik".
\end{abstract}

Kata kunci：Penilaian Kinerja, Guru Produktif, Standar Kompetensi Guru

\begin{abstract}
This study aims to assess teachers in education. This type of research is combination research (quantitative and qualitative). Research subjects were 55 people. The research data was obtained through questionnaires, peers, interviews, and data from the analysis using a percentage formula. The results of the study found that pedagogic competence: (1) for the questionnaire the average total score was 4.2. (2) For peer rankings average total score of 4.0, with the achievement level of respondents $80 \%$ remaining in the "good" category, (3) Average productivity score of 4.0, with an achievement level of respondents $80 \%$ in the category " good", and (4) For the results of interviews that discuss the principal, curriculum curriculum and 7 heads of productive majors, with the conclusion of the" good "category. While for the competence of the soul is obtained (1) For the questionnaire the total score is 4.3. (2) For the rank of peers the average total score is 4.2, with the achievement level of respondents $84 \%$ in the "good" category, (3) Average productivity score 4.1, with $82 \%$ respondents' achievement in the category " good ", and (4) For the results of interviews that discuss the principal, curriculum curriculum and 7 heads of productive departments with the" good "category.
\end{abstract}

Keywords : Performance Assessment, Productive Teachers, Teacher Competency Standards.

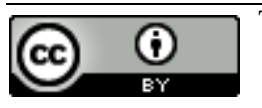

This is an open access article distributed under the Creative Commons 4.0 Attribution License.

\section{Pendahuluan}

Sekolah Menengah Kejuruan merupakan institusi pendidikan yang mewadahi proses dilakukannya pembelajaran sekaligus berperan sebagai lembaga untuk menyiapkan tenaga kerja tingkat menengah [1]. Dalam kegiatannya guru dan peserta didik berkumpul di sekolah dan tidak hanya sekedar berkumpul, tetapi berada dalam hubungan yang saling berkaitan di dalam tatanan organisasi. Pengelolaan pada suatu organisasi sangat dibutuhkan dan dipandang perlu terutama di sekolah. Lulusan sekolah kejuruan harus memiliki sumber daya manusia yang maksimal dan mampu bekerja memenuhi tuntutan masyarakat yang ada disekitarnya. Keberhasilan suatu sekolah atau tidak berhasilnya suatu sekolah dalam mempersipakan generasi yang siap bekerja akan sangat bergantung 
pada aktivitas pembelajaran yang dilakukan di sekolah [2].

Guru merupakan salah satu hal yang terpenting disekolah. Secara keseluruhan di dalam sistem pendidikan hal yang paling menentukan adalah komponen guru, menjadi sentral peserta didik dan harus mendapatkan perhatian, berbicara masalah pendidikan figur guru akan menjadi sosok yang strategis yang menjadi sorortan pertama dan utama, hal ini dikarenakan guru merupakan faktor terpenting di dalam dunia pendidikan, pembangunan pendidikan di indonesia sangat membutuhkan peranan penting seorang guru, khususnya yang dilakukan disekolah formal, keberhasilan peserta didik sangat bergantung pada gurunya, hal ini sebagaimana penelitian yang dilakukan [3] menyatakan the viability of the instructor is the major determinant of student scholarly advance. Terutama dalam kaitannya dengan kemajuan proses belajar mengajar.

Mutu pendidikan akan sangat dipengaruhi oleh guru yang bermutu. Dengan demikian jelas bahwa peranan peningkatan mutu pendidikan dipegang oleh guru . "Educational change depends on what teachers do and think" [4]. Dapat kita maklumi dari kenyataan, sekolah-sekolah tidak akan berdaya tanpa guru. Faktor kunci dari pembawa perubahan pada sekolah adalah guru karena mereka pasti akan berinteraksi dengan peserta didik atau siswanya. Hasilnya mutu pendidikan sekolah dipengaruhi oleh guru atau kinerja guru. Oleh sebab itu, apapun upaya perbaikan yang dilakukan dalam rangka meningkatkan kualitas pendidikan tidak akan dapat memberikan sumbangan yang berarti tanpa dorongan dan keterlibatan guru yang berkualitas dan profesional.

Makin baik mutu pendidikan sekolah atau kinerja gurunya akan berpengaruh pada pengetahuan, keterampilan dan motivasinya [5], maka diduga mutu pendidikan cenderung akan lebih baik. Kinerja guru mendidik di sekolah berpeluang besar akan melahirkan sumber daya manusia yang maju dalam bertindak kedepannya. Dengan demikian mutu sekolah dan kinerja guru perlu menjadi perhatian agar tercapai sekolah dan guru yang berkualitas dan menjadi harapan bangsa dan secara terus menerus musti meningkatkan kualitas pendidikannya. Secara umum pendidikan yang bermutu akan menjadi tolok ukur keberhasilan dari kinerja yang ditunjukkan oleh seorang guru.

Spesifikasi kinerja guru mempunyai kriteria tertentu dan dapat dilihat berdasarakan kompetensi yang dimiliki oleh seorang guru ,dan telah dikembangkan secara utuh menjadi 4 kompetensi utama, yaitu : (1) kompetensi pedagogik (2) kompetesi kepribadian (3) kompetensi sosial, dan (4) kompetensi profesional [6]. Kinerja guru dalam melaksanakan kompetensi guru sangat berpengaruh positif terhadap hasil belajar siswa [7] sehingga untuk mengetahui kinerja seorang guru dalam melaksanakan standar kompetensinya maka perlu dilakukan penilaian kinerja guru, hal ini bertujuan untuk mewujudkan guru yang professional. Untuk mewujudkan guru yang profesional perlu dilakukan penilaian kinerja guru dan dilakukannya penilaian kinerja guru bukan untuk menyulitkan guru, melainkan agar terwujudnya guru yang profesional [8].

SMK Negeri 8 Padang sebagai salah satu lembaga pendidikan formal tingkat menengah kejuruan di Sumatera Barat, tidak terlepas dari masalah-masalah yang ada, melalui observasi yang dilakukan kemudian dikuatkan dengan data wawancara dengan Kepala Sekolah dan beberapa orang guru produktif, dalam hal ini diperoleh informasi diantaranya : Kinerja guru dalam kompetensi pedagogik, belum optimal hal ini, ditandai dengan adanya lebih kurang $90 \%$ guru di sekolah ini belum mengumpulkan Perangkat Pembelajarannya secara lengkap, menyiapkan Perangkat Pembelajaran harus dikumpulkan oleh setiap guru pada awal bulan tahun ajaran baru, komponen Perangkat Pembelajaran adalah salah satu komponen yang terpenting yang ada dalam kompetensi pedagogik yang termasuk dalam sub indikator dari penilaian kinerja guru.

Pada sekolah ini, kinerja guru dalam kompetensi kepribadian menurut observasi awal yang dilakukan setiap hari senin selama satu semester, waktu pelaksanaan upacara bendera, para guru yang hadir sangat minim rata-rata terdapat lebih kurang $40 \%$ - $60 \%$ termasuk di dalamnya yang ikut upacara bendera adalah pegawai tata usaha. Sedangkan Kinerja guru dalam kompetensi sosial dan kinerja guru dalam kompetensi professional di sekolah ini selama observasi tidak ditemukan masalah.

\section{A. Penilaian Kinerja Guru}

Penilaian kinerja guru dilaksanakan pada kompetensi guru berdasarkan kewajiban melakukan pembelajaran, pembimbingan, atau pekerjaan tambahan yang sesuai dengan kepentingan sekolah. Penilaian adalah suatu langkah sistematis dan meliputi aktivitas menganalisis, menginterprestasikan serta mengumpulkan informasi yang bisa dimanfaatkan tentang karakteristik seseorang dan membuat 
kesimpulannya atau objek penentuan seberapa jauh guru meraih tujuan pembelajaran [9].

Penilaian kinerja bisa dipergunakan sebagai media untuk berkomunikasi di tempat kerja [10]. Sementara [11] mengemukakan penilaian kinerja guru merupakan kegiatan yang terstrukur dalam mengumpulkan, mengolah, menyusun dan menafsirkan data, informasi dan fakta dengan harapan dapat menyimpulkan ukuran atau peringkat seseorang dalam kompetensinya yang satu jenis/profesi pada bidang kehalian kependidikan. Lebih lanjut [12] penilaian kinerja guru adalah penilaian yang dilakukan pada setiap butir aktivitas tugas utama guru dengan tujuan pembinaan karir, jabatan dan kepangkatannya.

Cara penilaian yang salah satunya banyak digunakan dalam menetapkan kemampuan seseorang yaitu dengan melakukan aktivitas penilaian kinerja guru. Penilaian kinerja menurut [13] merupakan alat yang digunakan dalam bentuk manajemen yang dimanfaatkan untuk menaikkan kualitas penarikan keputusan dan kepercayaan. Bersumber pada penjelasan di atas disimpulkan penilaian kinerja guru produktif ialah merupakan prosedur yang terstruktur yang melingkupi aktivitas menganalisis, menginterprestasikan serta mengumpulkan penjelasan yang berguna sebagai pembuat kesimpulan mengenai karakter seseorang.

\section{B. Aspek-aspek yang Mempengaruhi Kinerja}

Aspek yang mempengaruhi kinerja guru ialah kecakapan (ability) dan aspek motivasi (motivation). Secara Psikologis, kecakapan guru terbagi atas kecakapan potensi (IQ) dan kecakapan reality (knowledge + skill). Artinya latar belakang pendidikan tinggi dan linier dengan bidangnya yang dimiliki oleh seorang guru seorang selanjutnya kompeten dalam melakukan pekerjaan sehari-hari, dengan demikian kinerja yang diharapkan akan lebih mudah dicapi oleh guru [14]. Situasi kerja yang dihadapi oleh guru akan membentuk motivasi dan sikap seorang guru. Selanjutnya untuk mencapai tujuan pendidikan yang terarah yang menggerakkan kondisi seseorang merupakan motivasi [14].

\section{Standar Kompetensi Guru}

Setiap individu guru harus memiliki kompetensi, agar dalam menjalankan tugasnya sebagai seorang pendidik dapat terarah. Competency berarti "kemampuan atau kecakapan." Selain memiliki arti kemampuan, kompetensi juga diartikan "the state of being legally competent or qualified, yaitu keadaan berwewenang atau memenuhi syarat menurut ketentuan hukum."'[15]. Dalam [16] dinyatakan kompetensi guru mancakup pedagogik, kepribadian, profesional dan sosial. Empat kompetensi utama seorang guru telah dikembangkan menjadi standar kompetensi guru, diantaranya ialah kompetensi pedagogik, kepribadian, sosial, dan profesional. Kinerja guru telah terintegrasi dalam empat kompetensi tersebut [17]. Bersamaan dengan hal itu, guru wajib menempuh pendidikan profesi agar memiliki kompetensi guru yang diantaranya kompetensi pedagogik, kepribadian, sosial dan profesional [18].

Adapun penjelasan dari empat kompetensi tersebut (1) kompetensi pedagogik yaitu mencakup pemahaman siswa, pelaksanaan dan perencanaan pembelajaran, evaluasi prestasi belajar, serta pengembangan siswa dalam rangka mengaktualisasi dari berbagai potensi yang ada padanya. (2) kompetensi kepribadian adalah kemampuan perorangan yang mewujudkan kepribadaian yang stabil, mantap, arif, dewasa, berwibawa, menjadi contoh untuk para siswanya serta berakhlak mulia. (3) kompetensi profesional yaitu materi pembelajaran yang dikuasai yang mencakup secara keseluruhan serta mendalam, yang meliputi materi kurikulum pada mata pelajaran sekolah dan juga hakikat keilmuan yang meterinya dinaungi, serta penguasaan pada struktur dan metode keilmuan. Dan (4) kompetensi sosial adalah kemampuan seorang guru dalam berkomunikasi antar sesama dan juga bergaul dengan efektif terhadap siswa, dengan pendidik lain, tenaga kependidikan, wali siswa, dan masyarakat umum disekitarnya.

\section{Indikator Penilaian Kinerja Guru}

Adapun beberapa indikator penilaian kinerja guru yang dapat dilihat yaitu diantaranya : (a) Kompetensi pedagogik, yaitu (1) Karakter peserta didik dikuasai oleh guru (2) Prinsip-prinsip pembelajaran dan teori belajar yang mendidik harus dikuasai oleh guru (3) Kurikulum yang dikembangkan (4) Aktivitas pembelajaran yang mendidik (5) Potensi peserta didik yang dikembangkan (6) guru berkomunikasi dengan peserta didik (7) Melakukan evaluasi dan penilaian (b) Kompetensi kepribadian, yaitu (1) Etos kerja, tanggung jawab yang tinggi, rasa bangga menjadi guru (2) Bertindak sesuai norma agama, hukum, sosial, dan kebudayaan nasional (3) Menunjukkan pribadi yang dewasa dan teladan. (c) Kompetensi sosial yaitu, (1) Komunikasi dengan sesama guru, tenaga kepndidikan, orang tua, peserta didik, dan 
masyarakat (2) Bersikap inklusif, bertindak objektif, serta tidak diskriminatif. (d) Kompetensi Profesional yaitu (1) Mengembangkan keprofesionalan melalui tindakan yang reflektif (2) Penguasaan materi, struktur, konsep, dan pola pikir keilmuan yang mendukung mata pelajaran yang diampu [18].

\section{E. Strategi Peningkatan Kinerja Guru}

Kinerja guru yang rendah tentunya membuat kepala sekolah gundah. Mutu pendidikan akan menurun dengan rendahnya kinerja guru dan visi misi sekolah kejuruan akan terhambat. Lulusan yang unggul dan memiliki daya saing dikancah global tidak akan mampu dihasilkan oleh sekolah kejuruan yang rendah kinerja gurunya. Oleh sebab itu, pengelolaan kinerja guru harus dilakukan dengan baik serta dipelihara sehingga tidak mengalami penurunan kinerjanya.

Ada dua langkah vital yang bisa dibuat agar menaikkan kinerja guru, meliputi "pelatihan dan motivasi kerja". Pelatihan dimanfaatkan sebagai wadah membenahi kinerja guru yang rendah, sedangkan motivasi kinerja dimanfaatkan sebagai media pemberi semangat kerja dan gairah kerja. Keseriusan penggunaan dua langkah demikian bergantung pada keadaan guru yang bersangkutan. Terlebih lagi, bila memang dibutuhkan, dengan cara simultan keduanya bisa digunakan [19].

\section{Metode}

Penelitian ini menggunakan jenis penelitian metode kombinasi (mixed methods). Jenis penelitian kombinasi ini merupakan metode yang menggabungkan atau mengkombinasikan metode kuantitatif dan metode kualitatif yang digunakan secara bersamaan pada suatu aktivitas penelitian, dengan demikian diperoleh data yang lebih komprehensif, reliabel, valid dan obyektif [20].

Data sekunder dan data primer digunakan pada penelitian ini. Subjek penelitiannya yaitu semua guru berstatus aparatur sipil negara yang mengajar pada mata pelajaran produktif yaitu sebanyak 55 orang.

Pengumpulan data dilakukan dengan jalan menemui para responden secara langsung dengan menggunakan: (1) Kuesioner (2) Penilaian teman sejawat (3) Observasi dan (4) Wawancara. Teknik keabsahan data kualitatif disebut juga dengan kredibilitas, merupakan istilah yang digunakan dalam penelitian kualitatif sebagai penentuan validitas, hal ini memerlukan langkah-langkah sebagai berikut: (1) Triangulasi (2) Peer Defriefing dan (3) Confirmability. Data yang terkumpul di analisis secara kuantitatif dan selanjutnya dijelaskan secara kualitatif, dengan demikian dalam pengolahan data penulis menempuh cara: (1) Editing (2) Tabulating (3) Skoring (4) melakukan analisis persentase dan (5) mendeskripsikan data penelitian.

Selanjutnya untuk data wawancara di analisis dengan interactive model, yaitu (1) Data reduction (2) Data display dan (3) Conclusion drawing [20].

\section{HaSil DAN PEMbahaSAN}

Hasil dan pembahasan yang dilakukan adalah sebagai berikut:

A. Kinerja Guru Produktif pada Kompetensi Pedagogik

Hasil penilaian kinerja guru dalam melaksanakan standar kompetensi guru yang berhubungan dengan kompetensi pedagogik pada instrumen : 1) Kuesioner, 2) Penilaian Teman Sejawat, 3) Observasi, dan 4) Wawancara, dalam tujuh sub indikator ialah : (1) Karakter peserta didik dikuasai oleh guru (2) Prinsip-prinsip pembelajaran dan teori belajar yang mendidik harus dikuasai oleh guru (3) Kurikulum yang dikembangkan (4) Aktivitas pembelajaran yang mendidik (5) Potensi peserta didik yang dikembangkan (6) guru berkomunikasi dengan peserta didik (7) Melakukan evaluasi dan penilaian yang berbentuk distribusi frekuensi bisa amati pada tabel 1 :

Tabel 1. Penilaian Kinerja Guru produktif pada

\begin{tabular}{|c|c|c|c|c|c|}
\hline No & Kuesione & Teman & Observas & Wawancar & \multirow{3}{*}{$\begin{array}{c}\text { Keputusa } \\
\mathrm{n}\end{array}$} \\
\hline Sub & $\mathrm{r}$ & Sejawat & $\mathrm{i}$ & $\mathrm{a}$ & \\
\hline $\begin{array}{l}\text { Indik } \\
\text { ator }\end{array}$ & Rerata & Rerata & Rerata & $\begin{array}{c}\text { Kesimpula } \\
\mathrm{n}\end{array}$ & \\
\hline 1 & 4,1 & 4,0 & 4,1 & Baik & Baik \\
\hline 2 & 4,2 & 4,0 & 4,1 & Baik & Baik \\
\hline 3 & 4,5 & 4,2 & 4,0 & Baik & Baik \\
\hline 4 & 4,2 & 4,1 & 4,0 & Baik & Baik \\
\hline 5 & 4,0 & 3,9 & 4,0 & Baik & Baik \\
\hline 6 & 4,3 & 3,9 & 3,9 & Baik & Baik \\
\hline 7 & 4,1 & 4,0 & 4,0 & Baik & Baik \\
\hline
\end{tabular}

Berdasarkan tabel diatas ada 7 sub indikator yang di evaluasi dengan instrumen: 1) kuesioner, 2) penilaian teman sejawat, 3) observasi, dan 4) wawancara yang rinciannya dapat dilihat pada gambar 1. 


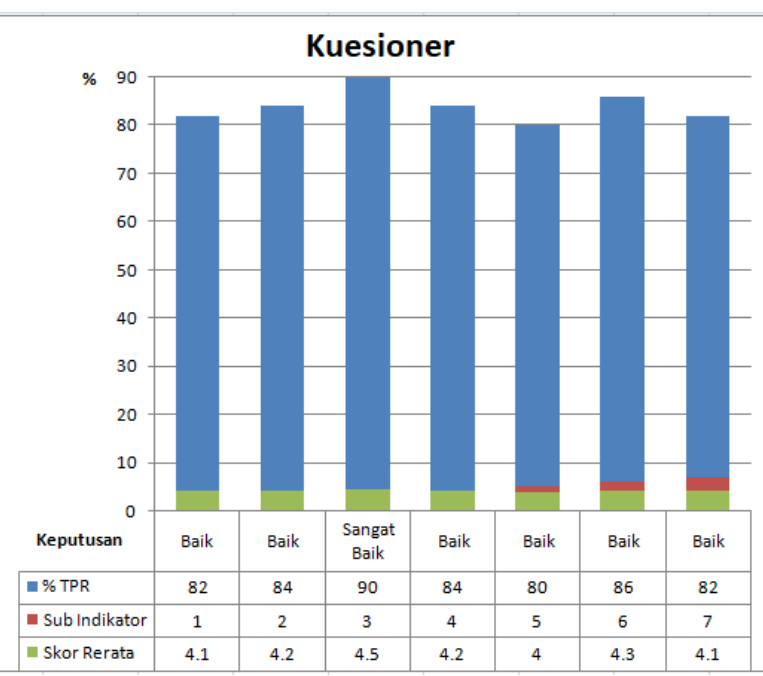

Gambar 1. Grafik kuesioner

Berdasarkan data hasil pengolahan dengan kuesioner yang disebarkan kepda guru produktif diperoleh skor rerata masing sub indikator (1) 4,1 dengan tingkat pencapaian responden $82 \%$ kategori baik, (2) 4,2, dengan tingakt pencapaian responden $84 \%$ kategori baik, (3) 4,5 dengan tingkat pencapaian responden $90 \%$ kategori sangat baik, (4) 4,2 dengan tingkat pencapaian responden $84 \%$ kategori baik, (5) 4,0 dengan tingkat pencapaian responden $80 \%$ kategori baik, (6) 4,5 dengan tingkat pencapaian responden $86 \%$ kategori baik, dan (7) 4,1 dengan tingkat pencapaian responden $82 \%$ kategori baik.

Berdasarkan data hasil pengolahan dengan penilaian teman sejawat yang disebarkan kepada guru produktif (lihat Gambar 2) diperoleh skor rerata masing sub indikator (1) 4,1 dengan tingkat pencapaian responden $80 \%$ kategori baik, (2) 4,2, dengan tingakt pencapaian responden $80 \%$ kategori baik, (3) 4,5 dengan tingkat pencapaian responden $84 \%$ kategori baik, (4) 4,2 dengan tingkat pencapaian responden $82 \%$ kategori baik, (5) 4,0 dengan tingkat pencapaian responden $78 \%$ kategori cukup baik, (6) 4,5 dengan tingkat pencapaian responden $78 \%$ kategori cukup baik, dan (7) 4,1 dengan tingkat pencapaian responden $80 \%$ kategori baik.

Berdasarkan data hasil observasi sejak tanggal 16 april 2013 - 22 mei 2013 terhadap 14 orang guru produktif yang masing-masingnya 2 orang pada 7 jurusan (lihat Gambar 3), diperoleh skor rerata masing sub indikator (1) 4,1 dengan tingkat pencapaian responden $82 \%$ kategori baik, (2) 4,2 , dengan tingakt pencapaian responden $82 \%$ kategori baik, (3) 4,5 dengan tingkat pencapaian responden $80 \%$ kategori baik, (4) 4,2 dengan tingkat pencapaian responden $80 \%$ kategori baik, (5) 4,0 dengan tingkat pencapaian responden $80 \%$ kategori baik, (6) 4,3 dengan tingkat pencapaian responden $78 \%$ kategori cukup baik, dan (7) 4,1 dengan tingkat pencapaian responden $80 \%$ kategori baik.

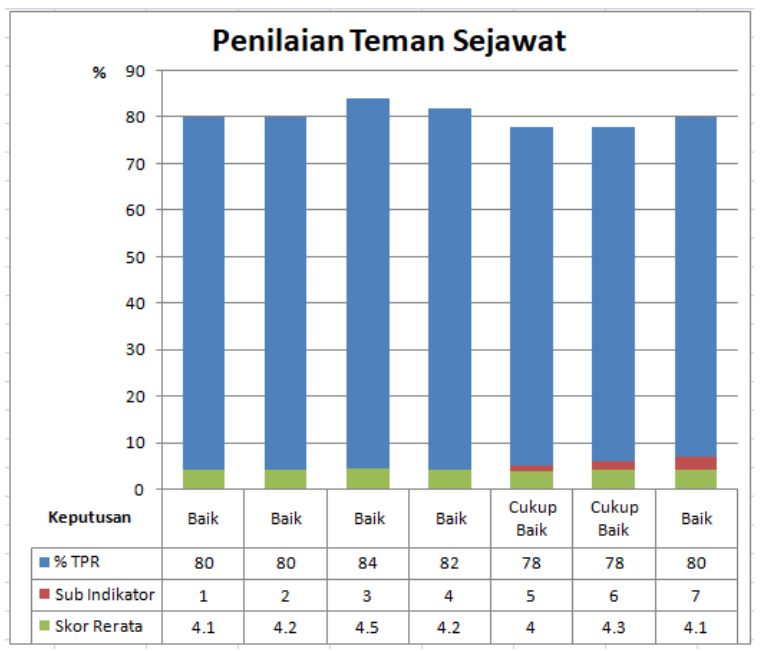

Gambar 2. Grafik penilaian teman sejawat

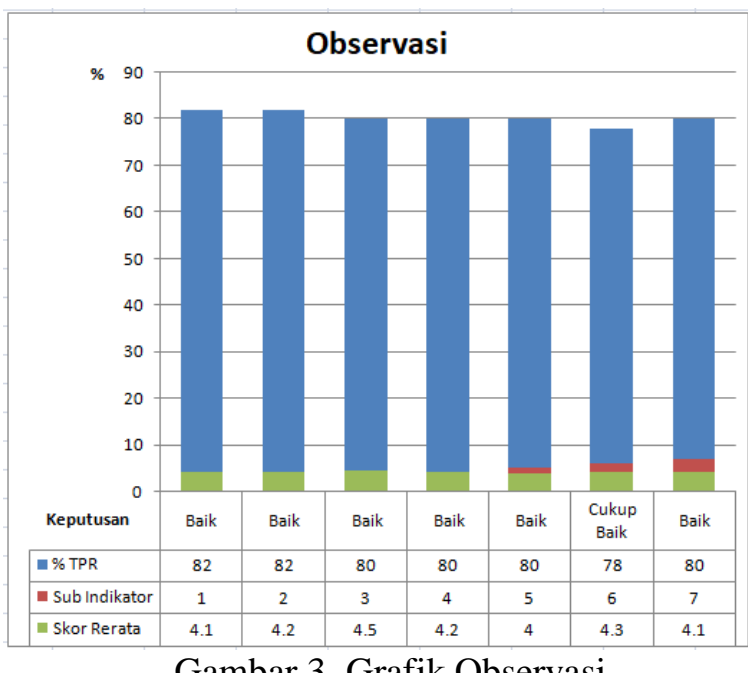

Gambar 3. Grafik Observasi

a. Instrumen Wawancara

Berdasrakan wawancara yang telah dilakukan kepada kepada sekolah, waka kurikulum dan ketua jurusan semua jurusan produktif dari tanggal 16 April 2013 - 22 mei 3013 yang menyangkut 7 sub va Teacher Competency Standards riabel diperoleh kesimpulan pada kategori "Baik".

Berdasarkan analisis deskriptif yang telah dilakukan terhadap variabel penilaian kinerja guru produktif di SMK Negeri 8 Padang dengan indikatornya kompetensi pedagogik yang terdiri dari 7 sub indikator dari 55 orang guru produktif subjek penelitian diperoleh skor rata-rata 186,5 dan skor maksimal ideal 220, didapat tingkat pencapaian respondennya sebesar $85 \%$ yang termasuk dalam kategori baik. 
Observasi yang telah dilakukan terhadap variabel penilaian kinerja guru produktif di SMK Negeri 8 Padang dengan indikatornya kompetensi pedagogik yang berdasarkan pedoman observasi terstruktur yang telah disusun yang terdiri dari 14 aspek yang di observasi, juga menguatkan temuan data diatas, didapati dari 14 orang guru produktif yang terdiri dari 7 jurusan, yang masing-masingnya di observasi 2 orang guru produktif sebagai sampel tujuan diperoleh skor rata-rata 56,3 dan skor maksimal ideal 70, didapat tingkat pencapaian respondennya sebesar $80 \%$ yang termasuk dalam kategori baik.

Hal tersebut diatas didukung dengan data dari penilaian teman sejawat yang telah dilakukan diperoleh skor rata-rata 48,9 dan skor maksimal ideal 60, didapat tingkat pencapaian respondennya sebesar $82 \%$ yang termasuk dalam kategori baik.

Observasi yang telah dilakukan diperoleh skor rata-rata 56,3 dan skor maksimal ideal 70, didapat tingkat pencapaian respondennya sebesar $80 \%$ yang termasuk dalam kategori baik.

Data diatas juga didukung kuat dengan hasil wawancara yang telah peneliti lakukan dengan kepala sekolah, waka kurikulum, dan 7 orang ketua jurusan yang bersangkutan yaitu (1) Ketua jurusan TKJ (Teknik Komputer Jaringan), (2) Ketua Jurusan TKR (Teknik Kendaraan Ringan), (3) Ketua Jurusan Kria Logam, (4) Ketua Jurusan Kria Kayu, (5) Ketua Jurusan Kria Tekstil, (6) Ketua Jurusan Kria Keramik, dan (7) Ketua Jurusan Busana Butik di SMK Negeri 8 Padang, di peroleh hasil berdasarkan mayoritas jawaban terbanyak yang diberikan pada kompetensi pedagogik diatas, dapat penulis simpulkan kompetensi pedagogik di SMK 8 Negeri pada kategori baik.

Menurut [17] Empat kompetensi utama seorang guru telah dikembangkan menjadi standar kompetensi guru, diantaranya ialah kompetensi pedagogik, kepribadian, sosial, dan profesional. Kinerja guru telah terintegrasi dalam empat kompetensi tersebut, Bersamaan dengan hal itu, guru wajib menempuh pendidikan profesi agar memiliki kompetensi guru yang diantaranya kompetensi pedagogik, kepribadian, sosial dan profesional [18]. Untuk mewujudkan guru yang profesional perlu dilakukan penilaian kinerja guru dan dilakukannya penilaian kinerja guru bukan untuk menyulitkan guru, melainkan agar terwujudnya guru yang profesional [8], karena kualitas layanan profesi yang bermutu ditentukan oleh harkat dan martabat suatu profesi". Dalam hal ini penilaian kinerja guru produktif dalam melaksanakan standar kompetensi guru telah dilakukan di SMK Negeri 8 Padang, hal ini agar kinerja guru dapat dievalusi tingkatannya secara perorangan dengan maksud kedepannya mencapai kinerja sekolah yang maksimal serta berpengaruh pada kenaikan hasil belajar siswa. Penilaian ini dilakukan sangat relevan dengan standar kompetensi guru, untuk mewujudkan guru yang profesional terutama pada kompetensi pedagogik.

Berdasarkan dari beberapa hasil data diatas, peneliti dapat disimpulkan bahwa variabel penilaian kinerja guru produktif di SMK Negeri 8 Padang dengan indikatornya kompetensi pedagogik dengan penguasaan kompetensi pedagogiknya sudah berada dalam kategori baik.

\section{B. Kinerja Guru Produktif pada Kompetensi Kepribadian}

Hasil penilaian kinerja guru dalam melaksanakan standar kompetensi guru yang berhubungan dengan kompetensi kepribadian pada instrumen: 1) Kuesioner, 2) Penilaian Teman Sejawat, 3) Observasi, dan 4) Wawancara, dalam tiga sub indikator yaitu: (1) Etos kerja, tanggung jawab yang tinggi, rasa bangga menjadi guru (2) Bertindak sesuai norma agama, hukum, sosial, dan kebudayaan nasional (3) Menunjukkan pribadi yang dewasa dan teladan. yang berbentuk distribusi frekuensi dapat dilihat pada tabel 2.

Tabel 2. Penilaian Kinerja Guru produktif pada Kompetensi Kepribadian

\begin{tabular}{cccccc}
\hline $\begin{array}{l}\text { No } \\
\text { Sub } \\
\text { Indik } \\
\text { ator }\end{array}$ & Kuesioner & $\begin{array}{c}\text { Teman } \\
\text { Sejawat }\end{array}$ & Observasi & Wawancara & \\
\cline { 2 - 5 } Kerata & Rerata & Rerata & Kesimpulan & \\
\hline 1 & 4,4 & 4,3 & 4,0 & Baik & Baik \\
\hline 2 & 4,4 & 4,2 & 4,2 & Baik & Baik \\
\hline 3 & 4,2 & 4,1 & 4,1 & Baik & Baik \\
\hline
\end{tabular}

Berdasarkan tabel diatas ada 3 sub indikator yang di evaluasi dengan instrumen: 1) kuesioner, 2) penilaian teman sejawat, 3) observasi, dan 4) wawancara yang rinciannya seperti pada gambar 4 , 5 dan 6.

Berdasarkan data hasil pengolahan dengan kuesioner yang disebarkan kepda guru produktif diperoleh skor rerata masing sub indikator (1) 4,4 dengan tingkat pencapaian responden $88 \%$ kategori baik, (2) 4,2, dengan tingakt pencapaian responden $88 \%$ kategori baik, dan (3) 4,2 dengan tingkat pencapaian responden $84 \%$ kategori baik.

Berdasarkan data hasil pengolahan dengan kuesioner yang disebarkan kepda guru produktif diperoleh skor rerata masing sub indikator (1) 4,3 dengan tingkat pencapaian responden $86 \%$ 
kategori baik, (2) 4,2, dengan tingakt pencapaian responden $84 \%$ kategori baik, dan (3) 4,1 dengan tingkat pencapaian responden $84 \%$ kategori baik. Berdasarkan data hasil observasi sejak tanggal 16 april 2013 - 22 mei 2013 terhadap 14 orang guru produktif yang masing-masingnya 2 orang pada 7 jurusan, diperoleh skor rerata masing sub indikator (1) 4 dengan tingkat pencapaian responden $80 \%$ kategori baik, (2) 4,2, dengan tingakt pencapaian responden $84 \%$ kategori baik, dan (3) 4,1 dengan tingkat pencapaian responden $82 \%$ kategori baik.

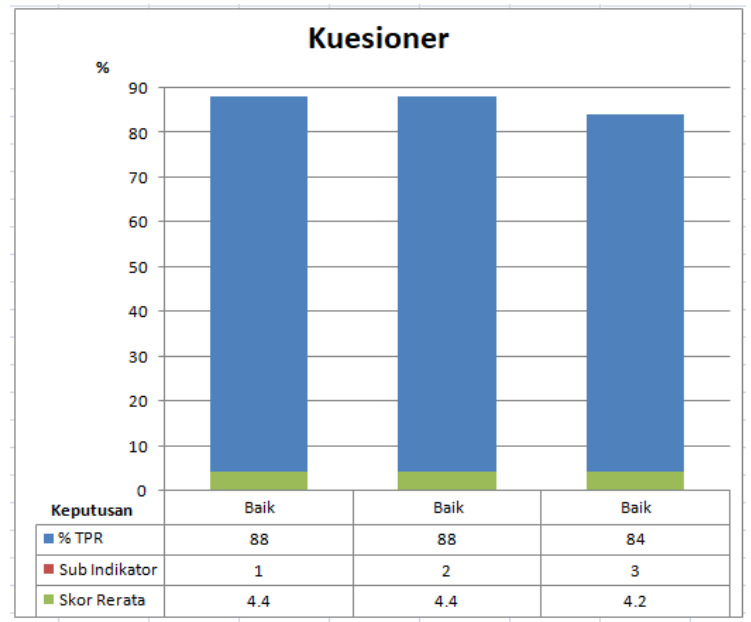

Gambar 4. Grafik dengan Kuesioner

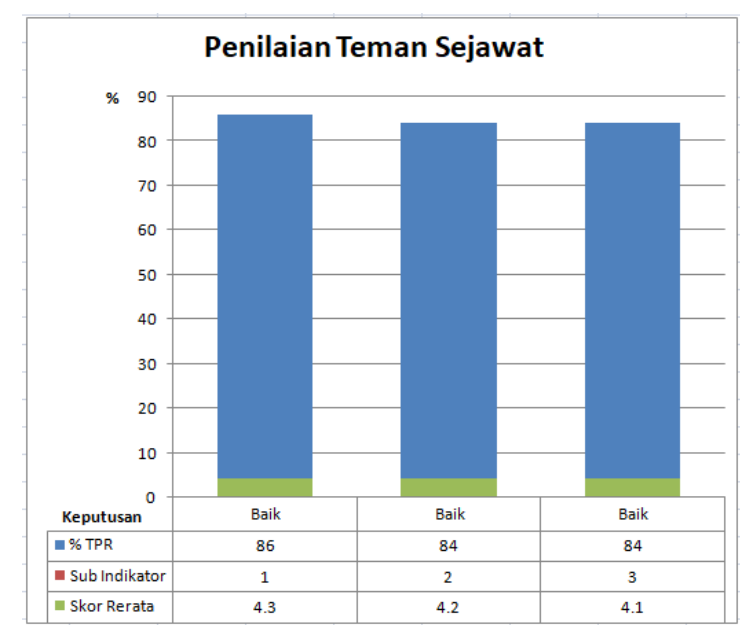

Gambar 5. Grafik dengan Penilaian Teman Sejawat

\section{a. . Instrumen Wawancara}

Berdasrakan wawancara yang telah dilakukan kepada kepada sekolah, waka kurikulum dan ketua jurusan semua jurusan produktif dari tanggal 16 April 2013 - 22 Mei 3013 yang menyangkut 3 sub variabel diperoleh kesimpulan pada kategori "Baik".

Berdasarkan analisis deskriptif yang telah dilakukan terhadap variabel penilaian kinerja guru produktif di SMK Negeri 8 Padang dengan indikatornya kompetensi kepribadian yang terdiri dari 3 sub indikator dari 55 orang guru produktif subjek penelitian diperoleh skor rata-rata 65,2 dan skor maksimal ideal 75, didapat tingkat pencapaian respondennya sebesar $87 \%$ yang termasuk dalam kategori baik.

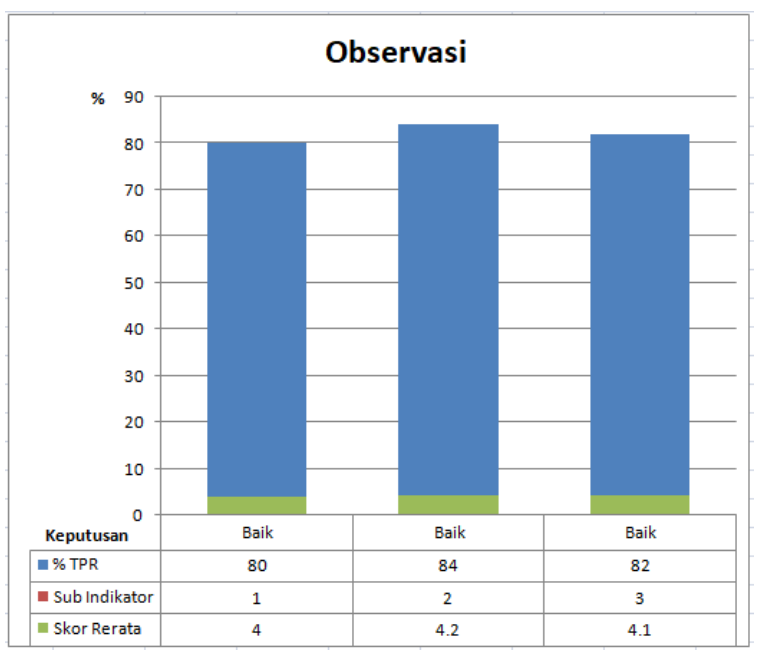

Gambar 6. Grafik dengan Observasi

Hal tersebut diatas didukung dengan data dari penilaian teman sejawat yang telah dilakukan terhadap variabel penilaian kinerja guru produktif di SMK Negeri 8 Padang dengan indikatornya kompetensi kepribadian yang terdiri dari 11 aspek yang dinilai, didapati dari 55 orang guru produktif subjek penelitian diperoleh skor rata-rata 45,7 dan skor maksimal ideal 55, didapat tingkat pencapaian respondennya sebesar $83 \%$ yang termasuk dalam kategori baik.

Observasi yang telah dilakukan terhadap variabel penilaian kinerja guru produktif di SMK Negeri 8 Padang dengan indikatornya kompetensi kepribadian yang berdasarkan pedoman observasi terstruktur yang telah disusun yang terdiri dari 7 aspek yang di observasi, juga menguatkan temuan data diatas, didapati dari 14 orang guru produktif yang terdiri dari 7 jurusan, yang masing-masingnya di observasi 2 orang guru produktif sebagai sampel tujuan diperoleh skor rata-rata 28,8 dan skor maksimal ideal 35, didapat tingkat pencapaian respondennya sebesar $82 \%$ yang termasuk dalam kategori baik.

Data diatas juga didukung kuat dengan hasil wawancara yang telah peneliti lakukan dengan kepala sekolah, waka kurikulum, dan 7 orang ketua jurusan yang bersangkutan yaitu (1) Ketua jurusan TKJ (Teknik Komputer Jaringan), (2) Ketua Jurusan TKR (Teknik Kendaraan Ringan), (3) Ketua Jurusan Kria Logam, (4) Ketua Jurusan Kria Kayu, (5) Ketua Jurusan Kria Tekstil, (6) Ketua 
Jurusan Kria Keramik, dan (7) Ketua Jurusan Busana Butik di SMK Negeri 8 Padang, diperoleh mayoritas jawaban terbanyak yang diberikan pada kompetensi kepribadian, dapat penulis simpulkan kompetensi kepribadian di SMK 8 Negeri pada kategori baik.

Menurut [17] Empat kompetensi utama seorang guru telah dikembangkan menjadi standar kompetensi guru, diantaranya ialah kompetensi pedagogik, kepribadian, sosial, dan profesional. Kinerja guru telah terintegrasi dalam empat kompetensi tersebut, Bersamaan dengan hal itu, guru wajib menempuh pendidikan profesi agar memiliki kompetensi guru yang diantaranya kompetensi pedagogik, kepribadian, sosial dan profesional [18]. Untuk mewujudkan guru yang profesional perlu dilakukan penilaian kinerja guru dan dilakukannya penilaian kinerja guru bukan untuk menyulitkan guru, melainkan agar terwujudnya guru yang profesional [8]. Dalam hal ini penilaian kinerja guru produktif dalam melaksanakan standar kompetensi guru telah dilakukan di SMK Negeri 8 Padang, hal ini agar kinerja guru dapat dievalusi tingkatannya secara perorangan dengan maksud kedepannya mencapai kinerja sekolah yang maksimal serta berpengaruh pada kenaikan hasil belajar siswa dan untuk mewujudkan guru yang profesional terutama pada kompetensi kepribadian.

Upaya untuk meningkatkan dan mengembangkan kinerja guru dalam melaksanakan standar kompetensi guru, khususnya di SMK Negeri 8 Padang pada dasarnya adalah kebutuhan yang tiada pernah berakhir terutama pada organisasi sekolah. Hal ini dikarenakan pengembangan dan peningkatan kinerja guru tidak hanya dilaksanakan bila ada kepincangan antara kinerja nyata dengan kinerja yang diminta, melainkan juga peningkatan dan pengembangan tersebut musti konsisten dilaksanakan walaupun belum terjadi kepincangan. Sebab dewasa ini perubahan lingkungan eksternal organisasi sekolah yang sangat cepat akan mendorong pada naiknya desakan yang lebih besar pada suatu organisasi sekolah.

Menurut [9] dua hal penting yang dapat dilakukan pada strategi untuk meningkatkan kinerja guru, ialah "pelatihan dan motivasi kerja". Rendahnya kemampuan guru dapat ditangani dengan pelatihan, sedangkan semangat kerja dan gairah kerja dapat ditangani dengan motivasi kinerja. Kedua strategi tersebut dapat digunakan dengan intensitas yang sesuai dengan kemampuan individu guru. Terlebih lagi, jika memang dibutuhkan, secara simultan keduanya dapat digunakan. Menurut observasi yang telah peniliti lakukan di SMK Negeri 8 Padang, upaya dalam meningkatkan kinerja guru dengan strategi pelatihan dan motivasi kerja sudah dilaksanakan pada guru-guru produktif di SMK Negeri 8 Padang, diantaranya dengan mengikuti diklat, lomba karya, bimtek, penataran, simposium dan rapat pengarahan dari kepala sekolah dan pengawas sekolah setiap tahun telah dilakukan.

Berdasarkan dari beberapa hasil data diatas, dapat disimpulkan bahwa variabel penilaian kinerja guru produktif di SMK Negeri 8 Padang dengan indikatornya kompetensi kepribadian dengan penguasaan kompetensi kepribadiannya sudah berada dalam kategori baik.

\section{KESIMPULAN}

Berdasarkan analisis dan pembahasan, maka penelitian dengan pendekatan deskriptif, jenis kombinasi antara kuantitatif dan kualitatif tentang penilaian kinerja guru produkitf dalam melaksanakan kompetensi guru dalam kompetensi pedagogik dan kepribadian, dapat disimpulkan sebagai berikut:

1. Kinerja guru produktif dalam melaksanakan kompetensi pedagogik di SMK Negeri 8 Padang berada pada ketegori baik yaitu (1) Untuk penilaian diri (kuesioner) skor total rata-ratanya 4,2, skor maksimal ideal 5 dengan tingkat pencapaian responden $84 \%$ dan berada dalam kategori baik, (2) Untuk penilaian teman sejawat skor total rataratanya 4,0, skor maksimal ideal 5 dengan tingkat pencapaian responden $80 \%$ dan berada dalam kategori baik, (3) Untuk observasi skor total rataratanya 4,0, skor maksimal ideal 5 dengan tingkat pencapaian responden $80 \%$ dan berada dalam kategori baik, dan (4) Untuk hasil wawancara yang diajukan kepada kepala sekolah, waka kurikulum dan 7 orang ketua jurusan produktif di SMK Negeri 8 Padang juga menguatkan data yang sebelumnya yaitu dengan kesimpulan berada dalam kategori baik.

2. Kinerja guru produktif dalam melaksanakan kompetensi kepribadian di SMK Negeri 8 Padang berada pada ketegori baik yaitu (1) Untuk penilaian diri (kuesioner) skor total rata-ratanya 4,3, skor maksimal ideal 5 dengan tingkat pencapaian responden $86 \%$ dan berada dalam kategori baik, (2) Untuk penilaian teman sejawat skor total rataratanya 4,2, skor maksimal ideal 5 dengan tingkat pencapaian responden $84 \%$ dan berada dalam kategori Baik, (3) Untuk observasi skor total rataratanya 4,1, skor maksimal ideal 5 dengan tingkat pencapaian responden $82 \%$ dan berada dalam 
kategori Baik, dan (4) Untuk hasil wawancara yang diajukan kepada kepala sekolah, waka kurikulum dan 7 orang ketua jurusan produktif di SMK Negeri 8 Padang juga menguatkan data yang sebelumnya yaitu dengan kesimpulan berada dalam kategori Baik.

\section{DAFTAR PUSTAKa}

[1] A. Ahyanuardi, H. Hambali, And K. Krismadinata, "Pengaruh Kompetensi Pedagogik Dan Profesional Guru Sekolah Menengah Kejuruan Pasca Sertfikasi Terhadap Komitmen Guru Melaksanakan Proses Pembelajaran," Invotek J. Inov. Vokasional Dan Teknol., Vol. 18, No. 1, Pp. 67-74, Jul. 2018.

[2] H. Hamdani and K. Krismadinata, "Kontribusi Kompetensi Dan Persepsi Tentang Supervisi Pembelajaran Terhadap Produktivitas Kerja Guru," Invotek J. Inov. Vokasional Dan Teknol., Vol. 17, No. 2, Pp. 61-66, Dec. 2017.

[3] W. L. Sanders and S. P. Horn, "Research Findings from the Tennessee Value-Added Assessment System (Tvaas) Database: Implications for Educational Evaluation and Research," J. Pers. Eval. Educ., Vol. 12, No. 3, Pp. 247-256, 1998.

[4] M. Fullan, "The New Meaning Of Educational Change," P. 32.

[5] Y. Indrawati, "Faktor-Faktor Yang Mempengaruhi Kinerja Guru Matematika Dalam Pelaksanaan Kurikulum Berbasis Kompetensi (Kbk) Pada Sekolah Menengah Atas Kota Palembang," P. 18.

[6] B. Sudibyo, "Menteri Pendidikan Nasional," P. 31.

[7] M. Inayah,R T. ,\& Sawiji, H., "Pengaruh Kompetensi Guru, Motivasi Belajar Dan Fasilitas Belajar Terhadap Prestasi Belajar Mata Pelajaran Ekonomi Pada Siswa Kelas Xi Ips Sma Negeri 1 Lasem Jawa Tengah Tahun Pelajaran 2011/2012 (Doctoral Dissertation, Universitas Sebelas Maret Surakarta)."

[8] Kemendikbud, "Tentang Pan \& Rb No 16 Tahun 2009.” 2012.

[9] Kusaeri Suprananto, Pengukuran Dan Penilaian Pendidikan. Yogyakarta: Graha Ilmu, 2012.

[10] H. Sadtyadi and B. Kartowagiran, "Pengembangan Instrumen Penilaian Kinerja Guru Sekolah Dasar Berbasis Tugas Pokok Dan Fungsi," J. Penelit. Dan Eval. Pendidik. Vol. 18, No. 2, Pp. 290-304, Dec. 2014.

[11] Pan \& Rb No 16 Tahun 2009. (Jakarta Kementerian Pendidikan Dan Kebudayaan 2012)..Pdf.".

[12] K. R. Prasetyowati And T. Sutojo, "Sistem Pendukung Keputusan Penilai Kinerja Guru (Pkg) Menggunakan Metode Simple Additive Weighting (Saw) (Studi Kasus) Sma Negeri 9 Semarang," P. 5.
[13] J. Pramono, "Analisis Pengukuran Kinerja Smk Negeri 6 Surakarta Dengan Pendekatan Balanced Scorecard," Balanc. Scorec. P. 21, 2014.

[14] Anwar Prabu Mangkunegara, Manajemen Sumber Daya Manusia. Bandung: Pt. Rosda Karya, 2000.

[15] Jamil Suprihatiningrum, Guru Profesional Pedoman Kinerja, Kualifikasi Dan Kompetensi Guru. Yogyakarta: Ar - Ruzzmedia, 2013.

[16] Depdiknas, "Undang-Undang No 14 Tahun 2015 Tentang Guru Dan Dosen," 2012.

[17] Depdiknas, "Undang - Undang No 16 Tahun 2007 Tentang Standar Kualifikasi dan Kompetensi Guru," 2012.

[18] Kementerian Pendidikan Nasional Direktorat Jenderal Peningkatan Mutu Pendidik Dan Tenaga Kependidikan 2010, "Kompetensi Dan Indikator Dalam Penilaian Kinerja Guru." Www.Bermutuprofesi.Org, 2013.

[19] Barnawi \& Mohammad Arifin, Kinerja Guru Profesional. Bandung: Ar - Ruzzmedia, 2012.

[20] Sugiyono, Metode Penelitian Kombinasi. Yogyakarta: Alfabeta, 2012.

\section{Biodata Penulis}

Dedi Setiawan, Menyelesaikan pendidikan Sarjana Pendidikan dan Magister Pendidikan Teknik dari Fakultas Teknik UNP. Saat ini aktif mengajar di Jurusan Teknik Otomotif Universitas Negeri Padang.

Hendra Dani Saputra, Menyelesaikan pendidikan Sarjana Pendidikan dan Magister Pendidikan Teknik dari Fakultas Teknik UNP. Saat ini aktif mengajar di Jurusan Teknik Otomotif Universitas Negeri Padang.

Muslim, Menyelesaikan pendidikan Sarjana Pendidikan dan Magister Pendidikan Teknik dari Fakultas Teknik UNP. Saat ini aktif mengajar di Jurusan Teknik Otomotif Universitas Negeri Padang.

R Chandra, Saat ini aktif sebagai salah satu dosen senior di Jurusan Teknik Otomotif Universitas Negeri Padang. 
